\title{
Surfaces
}

Lyotard, Jean-François. Lessons on the Analytic of the Sublime; (Kant's 'Critique of Judgment, ' [[section]][[section]]23-29). Trans. Elizabeth Rottenberg. Stanford University Press, 1994, 246 pp.

\section{Thomas Huhn}

Volume 4, 1994

URI : https://id.erudit.org/iderudit/1064984ar

DOI : https://doi.org/10.7202/1064984ar

Aller au sommaire du numéro

\section{Éditeur(s)}

Les Presses de l’Université de Montréal

ISSN

1188-2492 (imprimé)

1200-5320 (numérique)

Découvrir la revue

Citer ce compte rendu

Huhn, T. (1994). Compte rendu de [Lyotard, Jean-François. Lessons on the Analytic of the Sublime; (Kant's 'Critique of Judgment,'

[[section]][[section]]23-29). Trans. Elizabeth Rottenberg. Stanford University

Press, 1994, 246 pp.] Surfaces, 4. https://doi.org/10.7202/1064984ar d'utilisation que vous pouvez consulter en ligne. 


\title{
BOOK REVIEW
}

\author{
JEAN-FRANÇOIS LYOTARD, LESSONS ON THE ANALYTIC OF THE \\ SUBLIME.
}

\author{
Thomas Huhn
}

\begin{abstract}
Lyotard, Jean-François. Lessons on the Analytic of the Sublime; (Kant's 'Critique of Judgment,' [[section]][[section]]23-29). Trans. Elizabeth Rottenberg. Stanford University Press, 1994, 246 pp.
\end{abstract}

It is with a particular feeling that Jean-François Lyotard concludes his preface to this provocative reading of Kant's doctrine of the sublime:

If one had to summarize in a few words what is here said, one could say that these lessons try to isolate the analysis of a differend of feeling in Kant's text, which is also the analysis of a feeling of differend, and to connect this feeling with the transport that leads all thought (critical thought included) to its limits. $(x)$

Since for Lyotard the sublime is that which is "subjectively felt by thought as differend"(131), then in order to do justice to the limits of thought (and to bring thought to its limits), sublime feeling must remain irresolvable: "The admixture of fear and exaltation that constitutes sublime feeling is insoluble, irreducible to moral feeling"(127). We can likewise look neither to some dialectical synthesis nor to an aesthetics of beauty for a resolution of "sublime feeling" ("In the aesthetic of the beautiful the subject is in a state of infancy"[20]). For Lyotard the sublime in particular, and the aesthetic in general, is but a "supplement" -- the feeling between theoretical understanding and practical reason, between, that is, the first and second Critiques.

Although the scope of his "lessons" might at first glance seem quite constrained -- indeed the focus of his reading is limited to less than 40 pages of Kant's text -- the implications that Lyotard draws from these lessons are sweeping, for he places quite prominently Kant's contention that the third Critique is the key- stone in the architecture of the critical project as a whole. And yet one of the most interesting turns in Lyotard's book is the turn away from teleological judgment, just that which one might have expected him to turn toward in order to ground judgment (and its 
concomitant feeling) as the unifying, systematizing operation of thinking in general. Thus,

The reading that I advocate...admits that if the third Critique fulfills its mission of unifying the field of philosophy, it does so, not primarily by introducing the theme of the regulative Idea of an objective finality of nature, but by making manifest, in the name of the aesthetic, the reflexive manner of thinking that is at work in the critical text as a whole. (8)

(And, one might add, in the critical project of thinking as a whole.) What needs then to be made manifest, and what aesthetic judgment provides the most ideal and autonomous model of, is the manner according to which thinking occurs -- a manner invisible, or better not cognizable, in either theoretical knowledge or practical action, even though both these realms nonetheless flourish according to this same manner. In short, Lyotard reads Kant's Analytic of the Sublime as the problematic pursuit of the attempt to make manifest the principle of judgment as such: "the reflexive manner of thinking" according to the feeling (of differend) that heralds its appearance.

And yet curiously there is already on preliminary display in aesthetic judgment a manifestation of the principle of judgment in general, in that the former consists of the anomalous example of judgment proceeding according to principle but without concepts. But insofar as aesthetic judgment merely displays the supplemental nature of judgment in general, there is no knowledge to be had or practice to base upon it; hence for Lyotard there are lessons to be learned only from the limit-case example of the sublime. (Kant's efforts, for example, to keep "pure" aesthetic judgment free of charms, emotion, and concepts might well be interpreted according to Lyotard's schema as the preservation of the supplemental character of judgment). It is then only with the sublime that feeling (or thinking) comes fully into its own.

The first and longest of the nine chapters, entitled "Aesthetic Reflection," plots the course of Lyotard's avowedly "modest" lessons -- lessons which are also likened to a simple and self-enclosed explication de texte -- on Kant's Analytic of the Sublime. In what follows I trace out the explication of Kant plotted by Lyotard in his opening chapter. For Lyotard, just as the sublime is the key to Kant's aesthetics -- which in turn unlocks the critical project as a whole -- so is "feeling" the key to the sublime. And it is likewise here, in feeling, that we find not only the germ of Lyotard's reading of Kant, but come to understand his use in this text of the term "differend." Lyotard first recounts the well-known transition in meaning, from the first to the third Critique, of the term "aesthetic," and then comments:

Kant insists that the term 'sensation' that is 'a determination of the feeling of pleasure or displeasure'... is given a quite different meaning [etwas ganz anderes] from the sensation that is 'the representation of a thing.'(9) 
Aesthetic feeling, then, is the sensation not of a thing (or its representation) but of etwas ganz anderes, of differend, of that which cannot be represented or had. It is on the basis of just this distinction between "aesthetic" sensation of the first Critique and aesthetic "feeling" of the third Critique that a reader of Lyotard's book would expect him to forge an interpretation of Kant's aesthetics and the sublime. But rather than insisting on this distinction (and this is precisely what will make this book relevant to the entire Kantian critical project) Lyotard instead effaces it by claiming that judgment is already present in even the first Critique's notion of sensation: "It could be said that sensation is already an immediate judgment of thought upon itself"(10). (Thus, Lyotard's earlier contention that there is a pervasive "reflexive manner of thinking," which nevertheless only makes itself manifest in the aesthetic, must also be regarded as already fully present in sensation.)

Not only is judgment necessarily present in every sensation, but so too -- as an unavoidable counterpart -- Lyotard will claim, is reflection:

Any act of thinking is thus accompanied by a feeling that signals to thought its 'state'... For thought, to be informed of its state is to feel this state -- to be affected... Such is the first characteristic of reflection: a dazzling immediacy and a perfect coincidence of what feels and what is felt... Pure reflection is first and foremost the ability of thought to be immediately informed of its state by this state and without other means of measure than feeling itself. (11)

Lyotard's collapsing together of sensation, reflection, feeling and thinking are but a foreshadowing of the major implosion effected by his reading: the complete effacement of just that which the third Critique seems to attempt to universalize -- subjectivity itself. (Imagine sustaining a genuine intersubjectivity, produced by or premised upon aesthetic judgment, but without a substantive subject.) Lyotard arrives at the de-substantialization of the subject by way of the temporal nature of aesthetic feeling. Since the latter always occurs, as Kant insists, as a singular event which nonetheless promises universality and necessity, so then for Lyotard must the purported subject of the feeling be subject to its promissory character. Thus, "There is not one subjectivity that experiences pure feelings; rather, it is the pure feeling that promises a subject"(20). (One cannot help but be reminded here of both Stendhal's definition of beauty as the promise of happiness, as well as Harold Bloom's remarks regarding the necessary belatedness of literary form -- as if literature works to record the inevitable failure of the promise to be fulfilled.)

If taste is then the promise, whispered by aesthetic feeling, of a unified and unitary subject, this promise nonetheless encounters a fault and "abyss" (Kant's Abgrund) at the heart of the purported subject: between the faculties of imagination and reason. The feeling of the sublime is the name for that breach between the faculties: "Taste promises everyone the happiness of an accomplished subjective unity; the sublime speaks to a few of another unity, 
much less complete, ruined in a sense, and more 'noble'"(25). So although the sublime speaks of it as incomplete and ruined, it nonetheless still speaks of unity. The difference, however, is that for Lyotard the sublime does not "speak" to accomplish the unity of a subject but instead in order to "critique the notion of subject"(26). And it is with this notion of the critique performed by sublime feeling that we come to understand the great stress Lyotard places on the heuristic capacity of the sublime. The lessons of the sublime, strangely then, are utterly didactic since they flow from the reflective judgment that already "pre-logically" occurs within sensation itself. Sublime feeling is thus the performance -- the bringing out into the open (or at least to its limit) -- of the aporia that for Lyotard underlies not only all thinking but all sensation as well: the reflexive manner of cognition. Hence Lyotard, in what is perhaps his most sweeping gesture, reverses the priority within the distinction between determinant and reflective judgment -- just that distinction which Kant posits as the foundational premise for the third Critique. The reflective judgment within sensation is thus construed as excessively determinative of all the cognitive manners of subjectivity. This seditious, brilliant little book, full of hope and misprision, reads then as the most thoroughly Kantian commentary on the third Critique.

\section{Thomas Huhn \\ 16, W. 10th St. \#2R \\ NY, NY, 10011}

